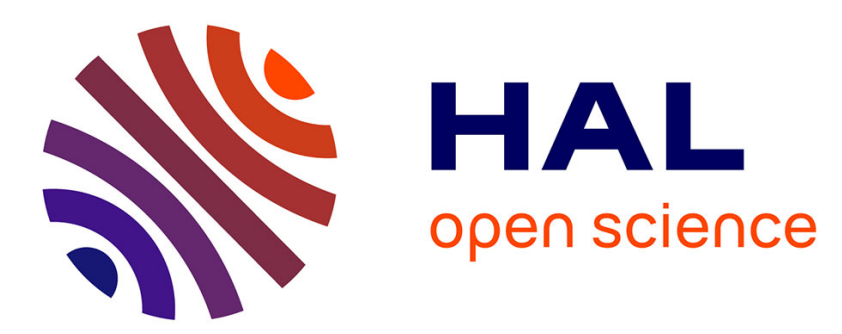

\title{
Prediction of drying of dairy products using a modified balance-based desorption method
}

\author{
Peng Zhu, Serge Méjean, Eric Blanchard, Romain Jeantet, Pierre Schuck
}

\section{To cite this version:}

Peng Zhu, Serge Méjean, Eric Blanchard, Romain Jeantet, Pierre Schuck. Prediction of drying of dairy products using a modified balance-based desorption method. Dairy Science \& Technology, 2013, 93 (4), pp.347-355. 10.1007/s13594-012-0099-9 . hal-01201418

\section{HAL Id: hal-01201418 \\ https://hal.science/hal-01201418}

Submitted on 17 Sep 2015

HAL is a multi-disciplinary open access archive for the deposit and dissemination of scientific research documents, whether they are published or not. The documents may come from teaching and research institutions in France or abroad, or from public or private research centers.
L'archive ouverte pluridisciplinaire HAL, est destinée au dépôt et à la diffusion de documents scientifiques de niveau recherche, publiés ou non, émanant des établissements d'enseignement et de recherche français ou étrangers, des laboratoires publics ou privés. 


\title{
Prediction of drying of dairy products using a modified balance-based desorption method
}

\author{
Peng Zhu • Serge Méjean • Eric Blanchard • \\ Romain Jeantet • Pierre Schuck
}

Received: 17 September 2012 / Revised: 12 November 2012 / Accepted: 22 November 2012 / Published online: 1 January 2013

(C) INRA and Springer-Verlag France 2012

\begin{abstract}
A desorption method based on a thermodynamic approach has recently been developed to evaluate the behaviour of dairy concentrates during drying. Involving overall heat and mass balance throughout the dryer, this approach can determine several key gas-feed parameters for industrial spray-drying processes. Spray-drying software $\left(\mathrm{SD}^{2} \mathrm{P}^{\circledR}\right)$ was then designed following this approach to predict the optimal inlet drying air temperatures with acceptable accuracy (95-99\% accuracy) for spray-drying of dairy products. However, the mass change of the sample was indirectly determined from the change in the relative humidity of the air during desorption, which could be a source of error below the detection threshold of the thermo-hygrometric sensor. In order to measure directly the mass change during drying by desorption, a modified drying-by-desorption method was investigated in this study. The novel method used a precise microbalance and a modified desorption cell which permitted measurement of the mass change of the sample and the relative humidity of the air at the same time. Different materials (water, skim milk, infant formulae, etc.) were tested using this new method. The results obtained with direct (microbalance) and indirect (thermo-hygrometer) measurements were found to be highly consistent (coefficient of determination 1). This confirmed that the mass change estimation by the original desorption method was correct overall under current conditions. Moreover, the proposed new desorption method makes it possible to monitor water transfer with constant accuracy over the entire desorption process,
\end{abstract}

P. Zhu • E. Blanchard

Laiterie de Montaigu, 85600 Montaigu, France

E. Blanchard

LISA.RD, 85600 Montaigu, France

S. Méjean $\cdot$ R. Jeantet $\cdot$ P. Schuck $(\bowtie)$

INRA, UMR1253, 35000 Rennes, France

e-mail: Pierre.Schuck@rennes.inra.fr

S. Méjean $\cdot$ R. Jeantet $\cdot$ P. Schuck

Agrocampus Ouest, UMR1253, 35000 Rennes, France 
thus permitting reliable study of the mass transfer phenomena throughout experiments.

Keywords Desorption - Spray-drying · Water transfer · Dairy product

\section{Introduction}

Spray-drying is a widely used technique to remove water from dairy products. The principle of this technique is to spray a concentrated liquid in individual small droplets and then mix them with hot air (temperature ranging from 100 to $300{ }^{\circ} \mathrm{C}$ ). Evaporation of water from the droplets is facilitated by the temperature and partial pressure gradients between the droplet and hot air. The temperature at the surface of the droplets is believed to be close to the wet bulb temperature, i.e., in the range of 30 to $50{ }^{\circ} \mathrm{C}$, and the total duration of drying is only a few seconds (Schuck et al. 1998; 2009). This technique can therefore provide reasonable preservation of the physiochemical and nutritional quality of the products.

Due to the increasing need for stringent product quality and strict function requirements, different dairy concentrates with a variety of constituents are currently spraydried. For example, the formulation of an infant formula may involve the mixing of over 40 different constituents before the evaporation and spray-drying processing stages. The differences in product composition may result in different drying behaviours, and the drying of such products may require adjustment of the spray-drying parameters. An inappropriate drying operation may lead to non-compliant product quality (physiochemical: water activity; nutritional: Maillard reaction; physical: cakiness and stickiness) and substantial economic losses.

There are two main methods to obtain optimal drying parameters for spray-drying of food products: the first is through empirical pilot experiments, but this method is usually expensive, time consuming and sometimes unreliable. The other method to determine the optimal drying parameters is through spray-drying modelling based on drying kinetics (Patel et al. 2010).

A drying-by-desorption method and 'Spray-drying parameter simulation and determination software' (SD2P ${ }^{\circledR}$ software) were developed in 2005 at the Institut National de la Recherche Agronomique in France (Schuck et al. 2009). This desorption method using an air-tight stainless-steel cylindrical cell (Fig. 1) to dry a milk concentrate sample $(160 \pm 1 \mathrm{mg})$ contained in a small plastic cup at $45{ }^{\circ} \mathrm{C}$. The desorption cell was filled with $120 \pm 1 \mathrm{~mL}$ zeolite particles (Zhu et al. 2011a). Water then transferred from the concentrate to the zeolites by means of the pressure gradient between the concentrate and the zeolites. Changes in the relative humidity of the air inside the cell during desorption were continuously monitored using a relative humidity sensor placed close to the surface of the milk sample. The change in relative humidity of the air between the concentrate and the zeolites can be measured by a thermo-hygrometric sensor connected to a computer, and the drying rate of the concentrate can be calculated from the desorption curve using the SD2P ${ }^{\circledR}$ software. By integrating several parameters of the dryer, the concentrate and the final product requirements (e.g. evaporation capacity, air flow rates and humidity, total solid contents and temperature of the 


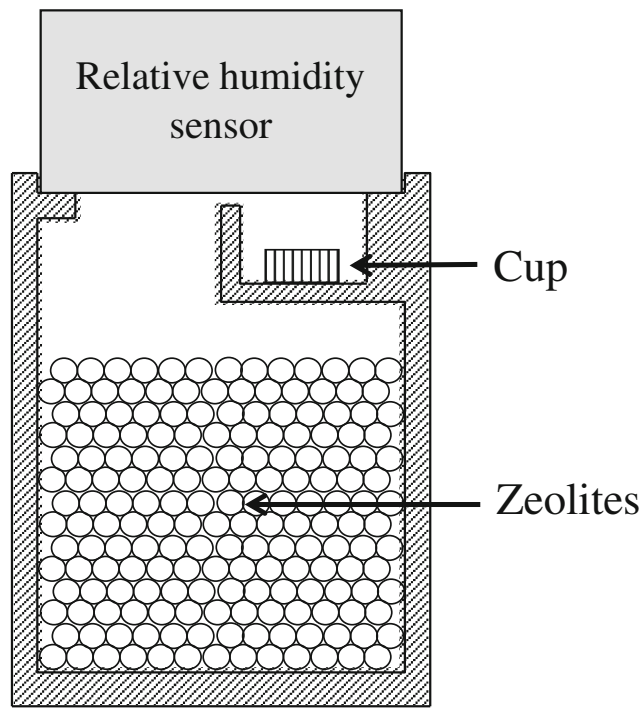

Fig. 1 Diagram of the original desorption experimental setup

concentrate, water content of the powder in relation to water activity, energy cost, etc.), the main operational parameters of spray-drying (e.g. inlet and outlet air temperatures, concentrate and powder flow rates, specific energy consumption, yield of the dryer and cost (per $\mathrm{kg}$ water evaporated or per $\mathrm{kg}$ powder produced)) can then be predicted from the mass and energy balance. Validation tests of over 30 different food concentrates have been performed using different spraydryers (evaporation capacity from $5 \mathrm{~kg} \cdot \mathrm{h}^{-1}$ to $6 \mathrm{t} \cdot \mathrm{h}^{-1}$ ), and a good match between measured and predicted parameters $( \pm 1-5 \%$ error) has been reported (Schuck et al. 2009).

In this method, the drying rate is evaluated indirectly from the change in the relative humidity by considering that the area below the relative humidity curve is representative of the quantity of evaporated water. However, the relative humidity values measured at the final stage of desorption are very low and close to the detection threshold of the thermo-hygrometric sensor. This could be a source of error for the calculation of mass change values. The aim of the current study was therefore to modify the existing desorption method to confirm whether such an indirect desorption method can predict the drying kinetics accurately during drying by desorption.

\section{Materials and methods}

\subsection{Preparation of the concentrates}

Concentrates with $40 \% w / w$ total solids were prepared from dairy powders dissolved in distilled water. The skim milk powder was produced at Bionov (Rennes, France). The infant formula powder was provided by the Laiterie de Montaigu (Montaigu, France). 


\subsection{Determination of total solid content}

Total solid content of the concentrates was measured according to the weight loss profiles after oven drying of $1 \mathrm{~g}$ of the sample mixed with sand at $105{ }^{\circ} \mathrm{C}$ for $7 \mathrm{~h}$.

\subsection{Drying-by-desorption method}

A new desorption cell has been designed to measure, at the same time, mass change and relative humidity change during desorption (Fig. 2). Similar to the original desorption cell (Fig. 1), the new desorption cell is filled with $120 \pm 1 \mathrm{~mL}$

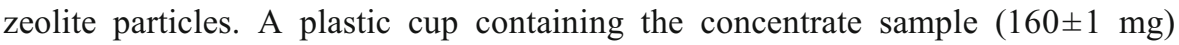
is placed in the middle of the cell and on the weighing platform of the microbalance $(\max 220 \mathrm{~g}, d=0.01 \mathrm{mg}$, model: wxts205du, Mettler Toledo, Viroflay, France). A relative humidity sensor (Rotronic, Bassersdorf, Switwerland) is placed on top of this desorption cell. The drying temperature of the original desorption method was $45^{\circ} \mathrm{C}$ (Schuck et al. 2009; Zhu et al. 2011a). However, due to the temperature range limit of the microbalance, the desorption temperature used in this study was fixed at $40{ }^{\circ} \mathrm{C}$. The duration of desorption was $300 \mathrm{~min}$. The changes in mass of the concentrate and of the relative humidity are recorded by computer every minute during drying by desorption. The desorption of skim milk was performed twice. The general standard deviations were $1.65 \mathrm{mg}$ and $0.6 \%$ for measured mass and relative humidity, respectively.

Using this new desorption cell, mass change can be obtained directly from the microbalance or indirectly from the relative humidity data.

Calculation of the mass change from relative humidity was based on the hypothesis that the area between the measured relative humidity curve and the bulk relative humidity $\left(\mathrm{RH}_{\mathrm{b}}\right)$ curve represents the amount of water evaporated during desorption (Fig. 3). The total water evaporated during desorption can be calculated from the difference between the initial $\left(m_{0}\right)$ and the final $\left(m_{\mathrm{f}}\right)$ mass weighed before and after desorption drying. Having established the total amount of water evaporated, the instantaneous water evaporated $\left(m_{t}\right)$ at time $t$ can thus be calculated from the relative humidity at time $t\left(\mathrm{RH}_{t}\right)$ and the cumulated relative humidity $\left(\mathrm{RH}_{\text {cumulated, }}\right.$ area between the relative humidity curve and the

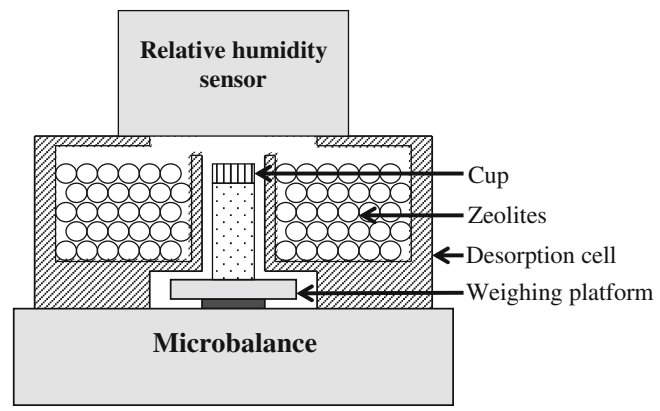

Fig. 2 Diagram of the new experimental desorption setup 


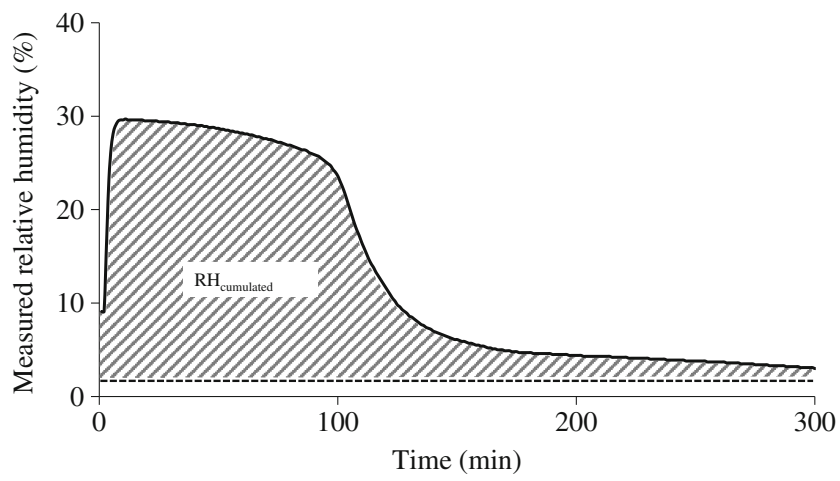

Fig. 3 An example of the desorption curve (line: measured relative humidity of $40 \% w / w$ total solids skim milk; broken line: bulk relative humidity of zeolite; $R H_{\text {cumulated }}$ : cumulated relative humidity)

bulk relative humidity), Eq. (1):

$$
m_{t}=\frac{R H_{t}-R H_{b}}{R H_{\text {cumulated }}} \times\left(m_{0}-m_{\mathrm{f}}\right)
$$

Then the mass change $(m)$ during the whole desorption drying process can be calculated from 1 to $300 \mathrm{~min}$, Eq. (2):

$$
m=\sum_{t=1}^{300} m_{t}
$$

The drying rate is calculated separately from measured mass change data and calculated mass change during the same desorption process. The mass change data measured by microbalance was taken every $10 \mathrm{~min}$ from the recorded raw data for the calculation of the drying rate. Then it is possible to compare the indirect method (calculate from relative humidity) with the direct method (measure by microbalance).

\section{Results}

Figure 4 shows the linear correlation between the measured and calculated mass changes obtained by the microbalance and relative humidity sensor, respectively, for distilled water (Fig.4a), 40\% w/w total solids skim milk (Fig. 4b) and 40\% w/w total solids infant formula (Fig. 4c) concentrates. Good correlation was obtained between the measured and calculated mass for water and the two concentrates under the drying conditions tested. The average differences between the measured and calculated mass values were $0.58 \pm 0.42,-0.03 \pm 0.55$ and $1.30 \pm 0.75 \mathrm{mg}$ for distilled water, skim milk and infant formula concentrates, respectively.

Figure 5 shows the drying rate of desorption calculated from the measured and calculated mass changes of distilled water (Fig. 5a), 40\% w/w total solids skim milk (Fig. 5b) and $40 \% w / w$ total solids infant formula (Fig. 5c) concentrates. For each of the three trials, the two curves exhibit approximately the same form. It can be seen that for distilled water, there was only one drying period up to $263 \mathrm{~min}$. Desorption of distilled water was at a fast drying rate during this period, with an average value of 

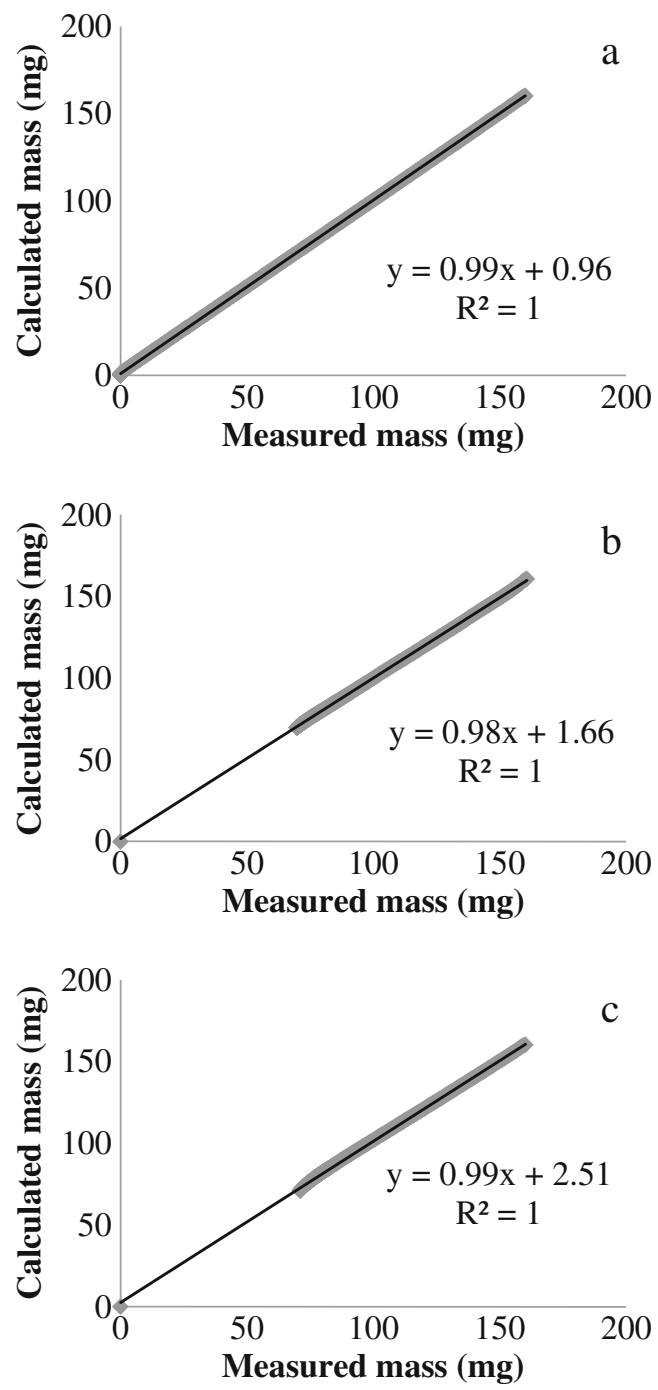

Fig. 4 Correlation between calculated and measured mass during drying by desorption of distilled water (a), $40 \% \mathrm{w} / \mathrm{w}$ total solids skim milk (b) and $40 \% \mathrm{w} / \mathrm{w}$ total solids infant formula (c)

$0.61 \mathrm{mg} \cdot \mathrm{min}^{-1}$ and the highest drying rate of $0.64 \mathrm{mg} \cdot \mathrm{min}^{-1}$. The drying rate of distilled water decreased slightly during desorption and reached approximately $0.50 \mathrm{mg} \cdot \mathrm{min}^{-1}$ at the end (263 $\left.\mathrm{min}\right)$. In contrast, two different periods can easily be distinguished for desorption of skim milk and infant formula concentrates from the drying rate curve: first a fast drying rate period (approximately from 11 to $110 \mathrm{~min}$ for skim milk and from 11 to 120 min for infant formula), and then a slow drying rate period (for duration higher than 110 and 120 min for skim milk and infant formula, respectively). The average drying rates in the fast drying rate period were $0.56 \mathrm{mg} \cdot \mathrm{min}^{-1}$ whatever the product, and the fastest drying rates were 0.61 and $0.58 \mathrm{mg} \cdot \mathrm{min}^{-1}$ for skim milk and infant formula concentrates, respectively. The 

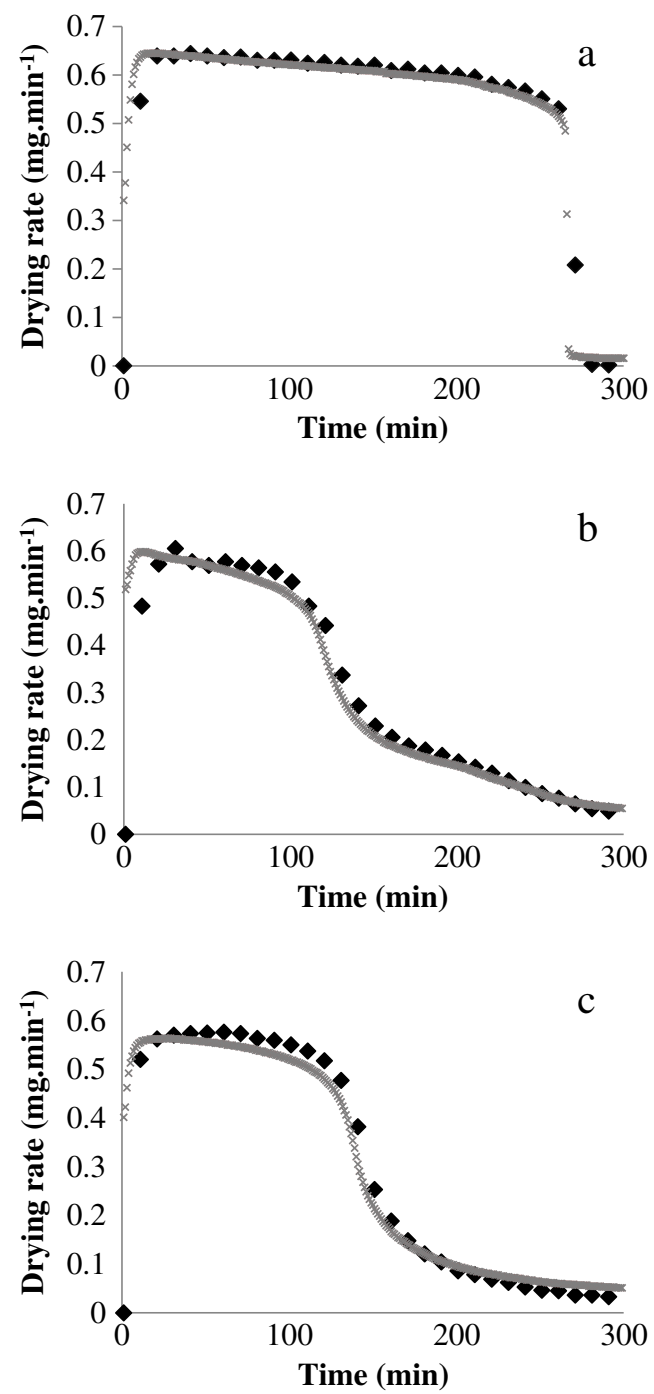

Fig. 5 Drying rate profiles obtained during drying by desorption of distilled water (a), $40 \% w / w$ total solids skim milk (b) and $40 \% \mathrm{w} / \mathrm{w}$ total solids infant formula (c) (diamond: by microbalance, cross: by relative humidity sensor)

average drying rates of the slow drying rate period were 0.16 and $0.13 \mathrm{mg} \cdot \mathrm{min}^{-1}$ for skim milk and infant formula concentrates, respectively.

\section{Discussion}

The first 10 min of desorption can be considered as the preheating stage (Zhu et al. 2011b). From 11 to $263 \mathrm{~min}$, the desorption of distilled water showed a fast drying rate (Fig. 5a). After this period, no more water was left in the plastic cup. As the thickness of the sample is only about $1 \mathrm{~mm}$, the slight decrease in drying rate may be 
explained by the reduction in the liquid surface when there is not enough water to cover the bottom of the plastic cup entirely due to the surface tension of water.

For the desorption of skim milk and infant formula concentrates (Fig. 5b, c), the existence of the fast and the slow dying rate period has been previously reported and explained by the relative easiness /difficulty to remove water, according to its binding to dairy constituents (Zhu et al. 2011b). These two periods have been observed and reported as well for single droplet drying at different drying conditions: higher drying air temperature $\left(70-110^{\circ} \mathrm{C}\right)$ to dry a lower initial solids concentration $(10-20 \% \mathrm{w} / \mathrm{w})$ (Lin and Chen 2006; Fu et al. 2011). This fast drying rate period was once considered as the constant drying rate stage (Zhu et al. 2011b). However, the results showed that the drying rate decreased during this period, mainly because of the increases in concentration and viscosity during evaporation of water.

The sudden decrease in drying rate in this period may relate to the formation of a crust at the surface of the concentrate along with an increase in viscosity and a decrease of free water to remove (Zhu et al. 2011b).

The drying temperature used in this study was $40{ }^{\circ} \mathrm{C}$ for both of the direct and indirect drying-by-desorption methods due to the temperature range limit of the microbalance. For all three trials, the results show a good correlation between the measured and calculated mass changes under the drying conditions tested (Fig. 4). The differences between measured and calculated mass values may be due to the accuracy of the relative humidity sensor, which is limited by temperature variation at the preheating stage and by low relative humidity values at the final stage of desorption drying. In contrast, using a microbalance gave constant accuracy over the entire desorption process, even at the final stage. The difference between measured and calculated mass values was never exceeding $1.30 \pm 0.75 \mathrm{mg}$ for the concentrates tested in this study. It is reasonable to believe that the original desorption method using a relative humidity sensor can be used to evaluate correctly the mass change of a concentrate during drying by desorption up to $300 \mathrm{~min}$, even at $45^{\circ} \mathrm{C}$. It is a simple and reliable method to provide drying kinetics of a concentrate for the $\mathrm{SD}^{2} \mathrm{P}^{\circledR}$ software.

\section{Conclusion}

A desorption method has been developed to evaluate the drying kinetics of a concentrate for a spray-drying software ( $\mathrm{SD}^{2} \mathrm{P}^{\circledR}$, Schuck et al. 2009). This method uses a relative humidity sensor to determine indirectly the mass change of a concentrate during drying by desorption. In order to evaluate the reliability of the original desorption method, a modified drying-by-desorption method was developed in this study. The modified method can measure directly the mass change during the drying by desorption process. Different materials (water, skim milk, infant formulae) were tested using this new method. The results obtained with direct (microbalance) and indirect (relative humidity sensor) measurements were found to be highly consistent under the drying conditions tested. This confirmed that the estimation of mass change by the original desorption method was correct overall under current conditions. The original desorption method using a relative humidity sensor is a simple and reliable method to provide drying kinetics for the $\mathrm{SD}^{2} \mathrm{P}^{\circledR}$ software. 
However, the proposed new desorption method makes it possible to monitor water transfer with constant accuracy over the entire desorption process, thus permitting further reliable study of mass transfer phenomena throughout experiments.

Acknowledgements The authors thank the Laiterie de Montaigu (France) for their scientific and financial support for this study.

\section{References}

Fu N, Woo MW, Lin XQ, Zhou Z, Chen XD (2011) Reaction engineering approach (REA) to model the drying kinetics of droplets with different initial sizes-experiments and analyses. Chem Eng Sci $66: 1738-1747$

Lin XQ, Chen XD (2006) A model for drying of an aqueous lactose droplet using the reaction engineering approach. Dry Technol 24:1329-1334

Patel K, Chen XD, Jeantet R, Schuck P (2010) One-dimensional simulation of co-current, dairy spray drying systems — pros and cons. Dairy Sci Technol 90:181-210

Schuck P, Roignant M, Brulé G, Davenel A, Famelart MH, Maubois JL (1998) Simulation of water transfer in spray drying. Dry Technol 16(7):1371-1393

Schuck P, Dolivet A, Méjean S, Zhu P, Blanchard E, Jeantet R (2009) Drying by desorption: a tool to determine spray drying parameters. J Food Eng 94:199-204

Zhu P, Méjean S, Blanchard E, Jeantet R, Schuck P (2011a) Prediction of dry mass glass transition temperature and the spray drying behaviour of a concentrate using a desorption method. J Food Eng 105:460-467

Zhu P, Patel K, Lin S, Méjean S, Blanchard E, Chen XD, Schuck P, Jeantet R (2011b) Simulating industrial spray drying operations using a reaction engineering approach and a modified desorption method. Dry Technol 29(04):419-428 